Darrell M. Drake

Edward D. Axthur

Myron G. Silbext 
This report was prepared as an account of work sponsored by the United States Government. Neither the United Staces nor the United Stotes Atomic Energy Commission. nor any of their amployees, nor any of their contractors, subcontractors, or their employees, makes any warranty, express or implied, or assumes any legal liability or responsibility for the accuracy, completeness or usefulness of any information, apparatus, product or process disclosed, or represents that its use would not infringe privately owned rights.

Printed in the United States at Armerica. Available from

National Technical Information Service

U.S. Department of Commerce

5285 Port Royal Road

Springfield, Virginia 22151

Price: Printed Copy $\$ 4.00$ Microfiche $\$ 1.45$ 


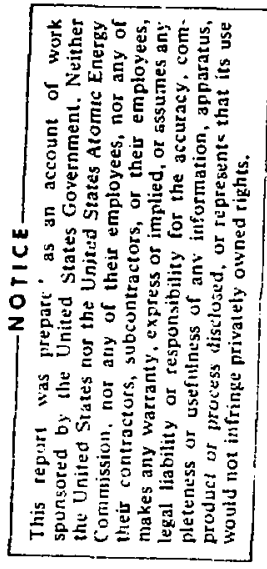

\title{
FOURTEEN-MEV, NEUTRON-INDUCED GAMMA-RAY PRODUCTION CROSS SECTIONS
}

by

\author{
Darrell M. Drake, Edward D. Arthur, and Myron G. Silbert
}

\begin{abstract}
$A$ pulsed 14.2-MeV neutron source and NaI(T1) gamma-ray spectrometer were used to measure gamma-ray production cross sections for carbon, magnesium, aluminum, chromium, iron, nickel, copper, molybdenum, niobium, tantalum, platinum, 235U, and ${ }^{23 \%} \mathrm{Pu}$.
\end{abstract}

\section{INTRODUCTION}

Gamma-ray production cross sections were measured for samples of carbon, magnesium, aluminum, chromium, iron, nickel, copper, molybdenum, niobium, tantalum , tatinum, ${ }^{235} \mathrm{U}$, and ${ }^{239} \mathrm{Pu}$ that wrere bombarded with a puised 14.2$\mathrm{MeV}$ neutron beam obtained from the ${ }^{\mathrm{H}} \mathrm{H}(\mathrm{t}, \mathrm{n})^{4} \mathrm{He}$ reaction. These cross sections are of interest for applications to the controlled thermonuclear reaction (CTR) program and to various other Laboratory programs.

\section{EXPERIMENTAL ARRANGEMENT}

Figure 1 shows the experimental arrangement. A chopped beam of tritons (10-ns time width at 2- $\mathrm{mHz}$ repetition rate) was accelerated to $2.3 \mathrm{MeV}$ by the Los Alamos Scientific Laboratory (LASL) Vertical Van de Graaff. The triton beam pulses were condensed to a time width of $1 \mathrm{~ns}$ and directed into a deuterium gas target. Neutrons, emitted at $90^{\circ}$ to the triton beam with a mean energy of $14.2 \mathrm{MeV}$, interacted with one of the samples placed about 100 $\mathrm{mm}$ from the neutron source. The energy spread of the neutrons intercepted by the samples was about $\pm 0.5 \mathrm{MeV}$. Gamma rays produced from the bombarded samples were collimated and pulse-height analyzed by a heavily shielded $\mathrm{NaI}(\mathrm{Tl}$ ) crystal and photomultiplier system. An anti-Compton NaI(Tl) scirtillator surrounding the center crystal was used to suppress further the bcckground events and to improve the response functions. The pulsed neutron beam allowed time-of-flight (TOF) discrimination by sorting out the desired gamma rays from neutronrelated and other background events in the crystal.

\section{DATA REDUCTION}

\section{A. Background Subtraction}

Figure 2 shows a relative time spectrum of NaI(Tl) pulses. Time gates were set as indicated to record ilses with differing time relationships relative to a fiducial time signal from a beam pickoff loop. Gate 1 covered the time region contrining prompt gamma rays directly from the sample. Gate 2 was set to cover a time region before the neitrons from a pulse had arrived at the scmple and therefore was a measure of

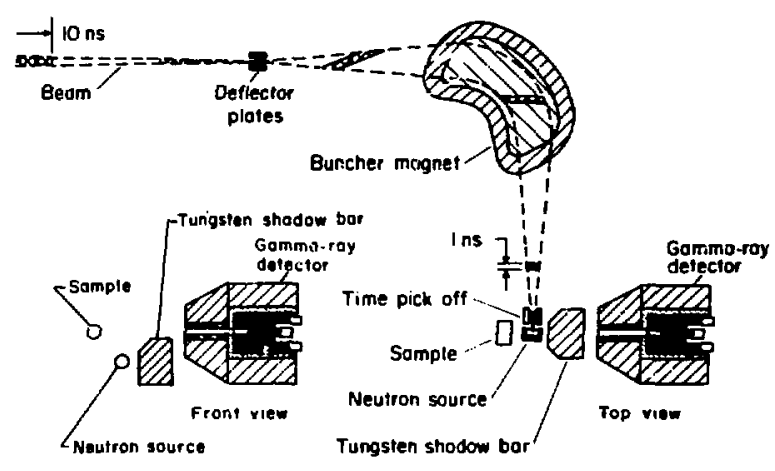

Fig. 1.

Experimental arrangement for the measurements of gamma-ray spectra. The detector and sample are about $100 \mathrm{~mm}$ above the plane defined by the beam path. 


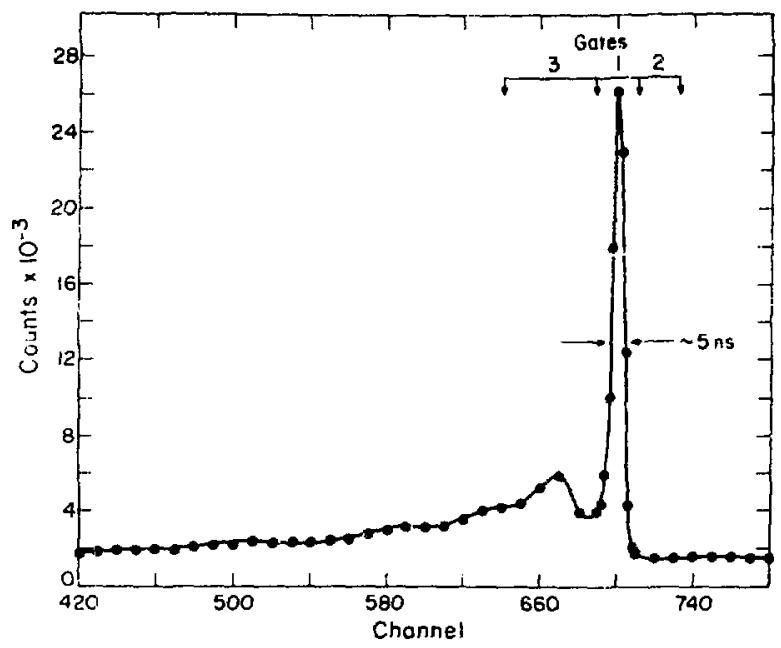

Fig. 2.

Time spectrum of pulses in the gamma-ray detector relative to the beam burst pickoff time. Gate 1 corresponds to gamma rays made in the sample due to the burst of neutrons. Gate 2 corresponds to a time-independient background. Gate 3 corresponds to fast neutron interactions in the Nal crystal.

time-independent background. Gate 3 covered times after the direct gamma rays had arrived at the scintillator and therefore was assumed to correspond to neutron-related events in the crystal that were delayed by the neutron TOF.

The lirst step in date reduction wcs to subtract the background pulse-height spectrum of Gate 2. properly normalized, from the pulse-height spectrum defined by Gate 1. Next, a separate spectrum, measured with no sample in position and the same time gates, was subtracted to obtain a net pulseheight spectrum.

The net spectra for the samples used in this experiment (except for iron) are shown in Figs. 3 through 14. Figure IS shows the pulse-height spectrum for iron before subtracting the no-sample spectrum. This figure also shows the corresponding no-sample spectrum. The computer program NIBL converted the net pulse-height spectra to gamma-ray spectrc, using knowledge of the NaI(Tl) spectrometer's response to monoenergetic gamma rays.

\section{B. Response Functions}

The response functions and efficiencies used in analyzing the experimental data were obtained by measuring the gamma-ray line shapes of calibrated

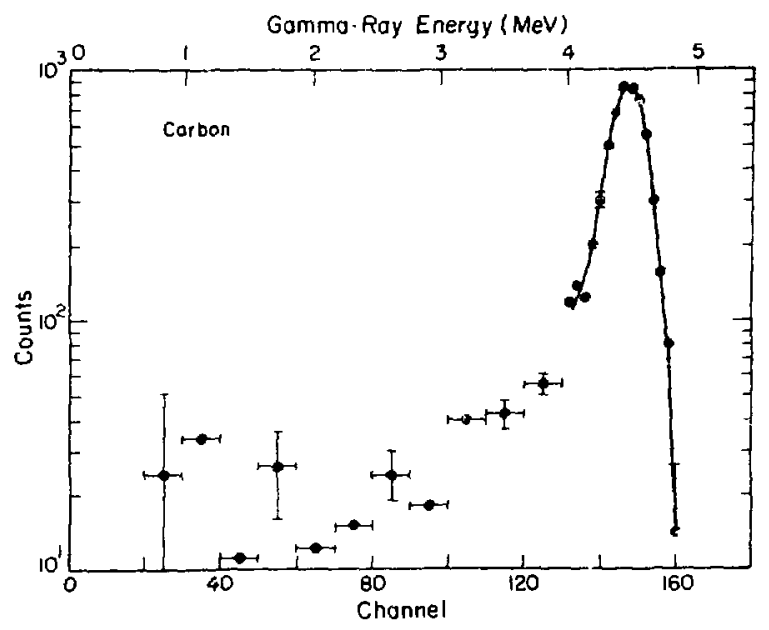

Fig. 3.

Net gamma-ray pulse-height spectrum for carbon.

sources over the $0.28-$ to $4.4-\mathrm{MeV}$ energy range. The response functions are shown in Fig. 16 for 4.4-, 2.75-, 1.37 , and $0.66-\mathrm{MeV}$ lines originating from neutronbombarded carbon, ${ }^{24} \mathrm{Na}$, and ${ }^{137} \mathrm{Cs}$ radioactive sources. The unfolded spectra (not corrected for efficiency) strongly resemble the net pulse-height spectra because the response fanctions have such $\alpha$ faworable peak-to-tail ratio.

The samples used in the collection of experimental data influence the shaps of the gamma-ray response function; therefore, the response measuremonts were made so as to account for these sample-depandent effects. For example, Fig. 17 shows the garnma-ray

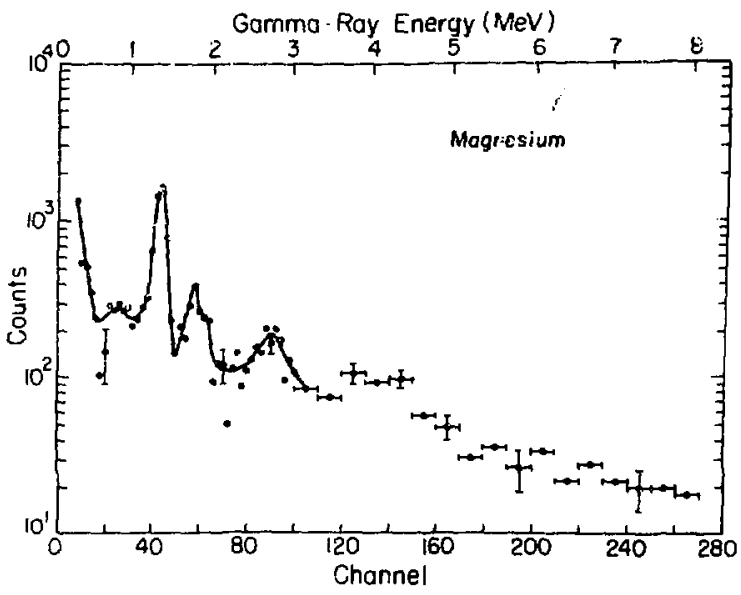

Fig. 4.

Net gamma-ray pulse-height spectrum for magnesium. 


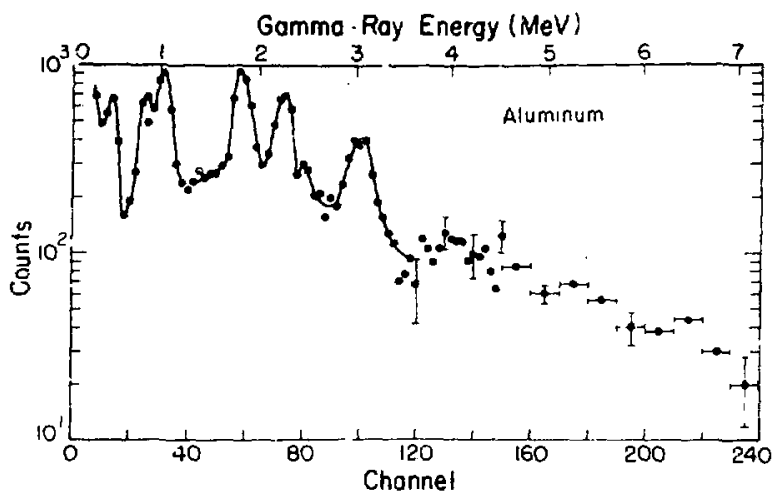

Fig. 5.

Net gamma-ray pulse-height spectrum for aluminum.

pulse-height spectrum for the 1.27-MeV gamma ray from $22 \mathrm{Na}$ for a bare source and for the situation where a 0.32 -mm-thick iron absorber was placed between the source and the detector. With the iron absorber in place, the ratio $\mathrm{R}$ (number of counts in the tril extending from 'se full energy peak to zero energy to the total number of counts in the tril plus peak) increased over the same ratio for the bare source case. The effect results from two phenomena. (1) The gamma rays were degraded in energy by scattering in the sample and were added to the number of counts occurring in the tail, and (2) the unmber of counts in the peak was decreased by the expected amount as a result of absorption and scattering.

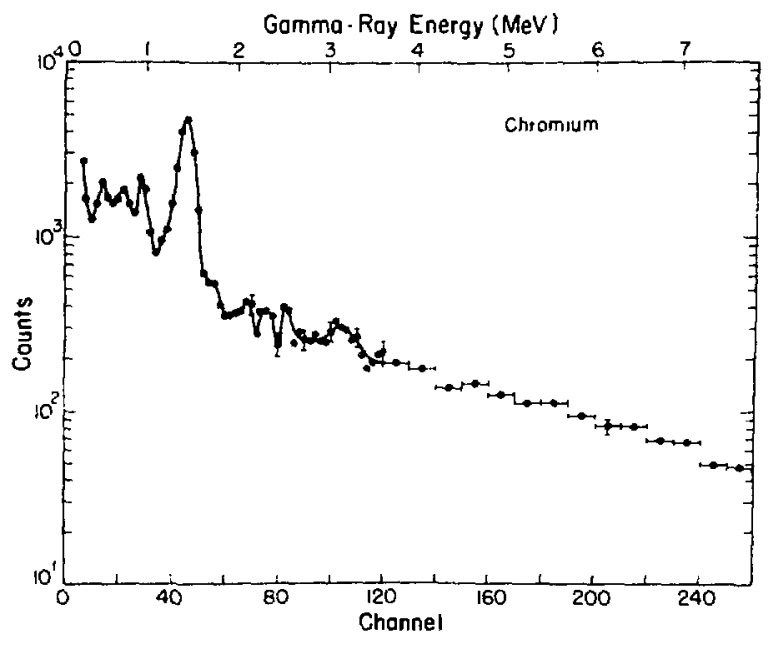

Fig. 6.

Net gamma-ray pulse-height spectrum for chromium.

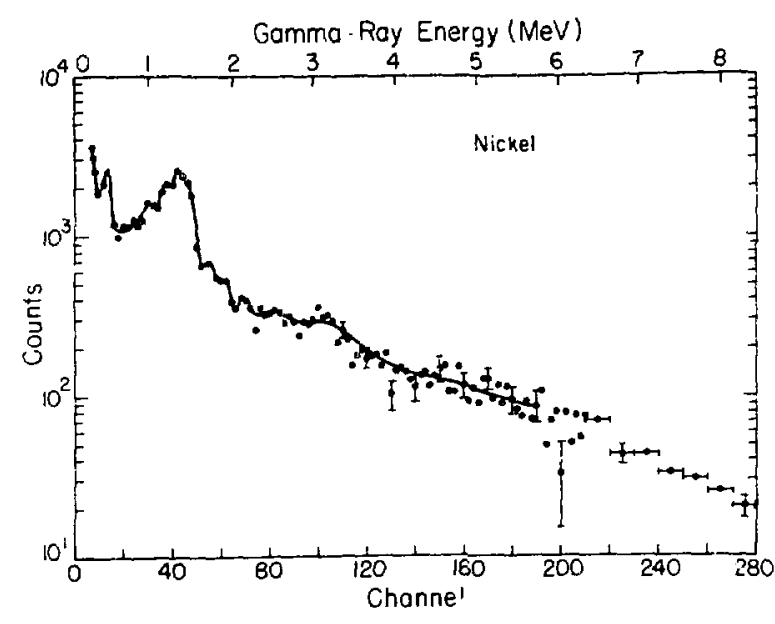

Fig. 7.

Net gamma-ray pulse-height spectrum for nickel.

To simulate the geometry of the samples actually used to obtain the experimental data, response measurements were made for situations where sources were placed inside a thin-walled iron cylinder, between two thin iron disks, as well as isolated sources. The ratio of counts in the tail divided by counts in the tail plus counts in the peak (after correction for gamma-ray absorption) was determined for these source geometries.

An estimate of the sample geometry effect was made to extend these measurements to other samples. Details of this calculation are described in

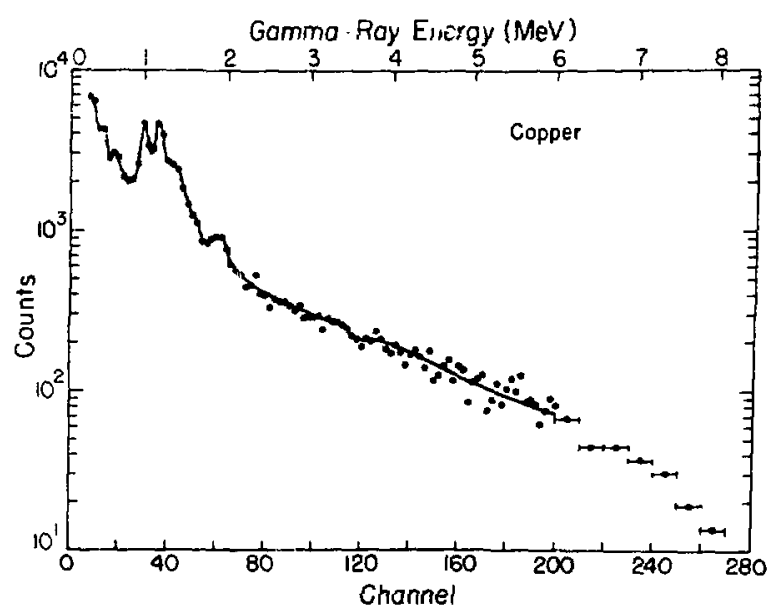

Fig. 8.

Net gamma-ray pulse-height spectrum for copper. 


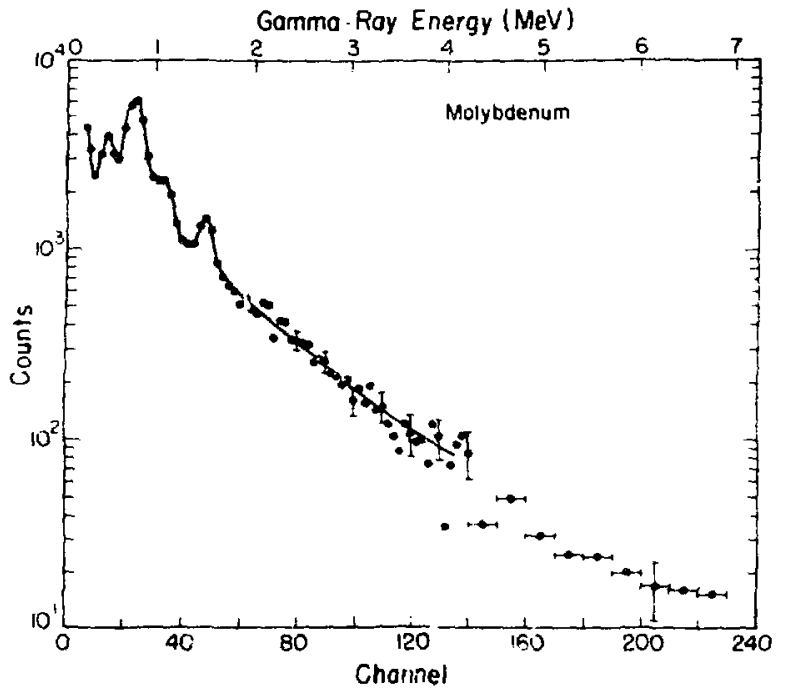

Fig. 9.

Net gamma-ray pulse-height spectrum fo: molybdenum.

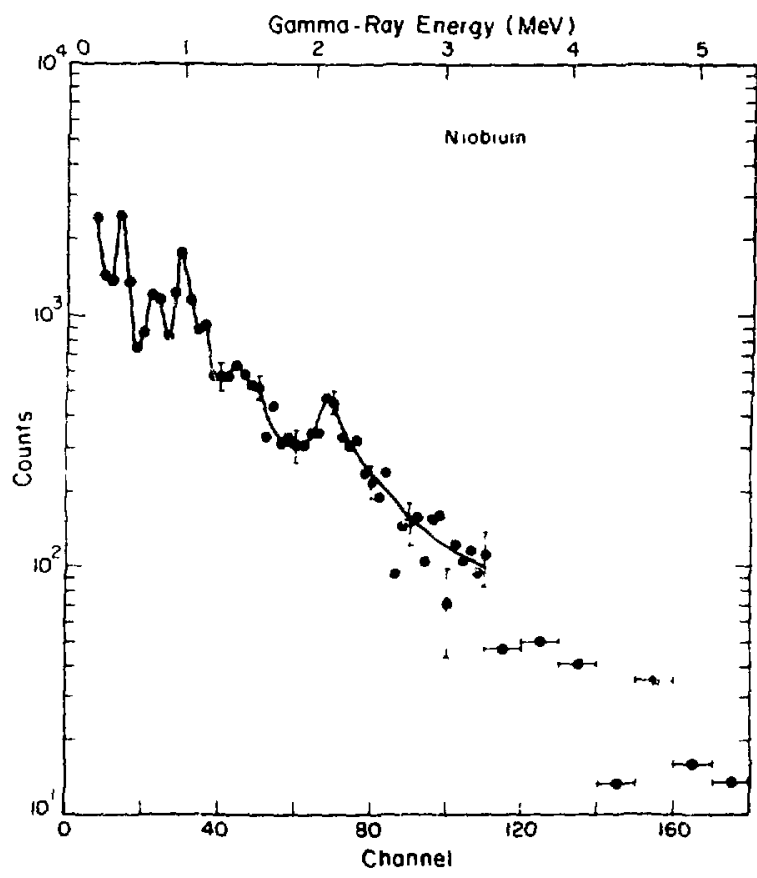

Fig. 10.

Net gamma-ray pulse-height spectrum for niobium.

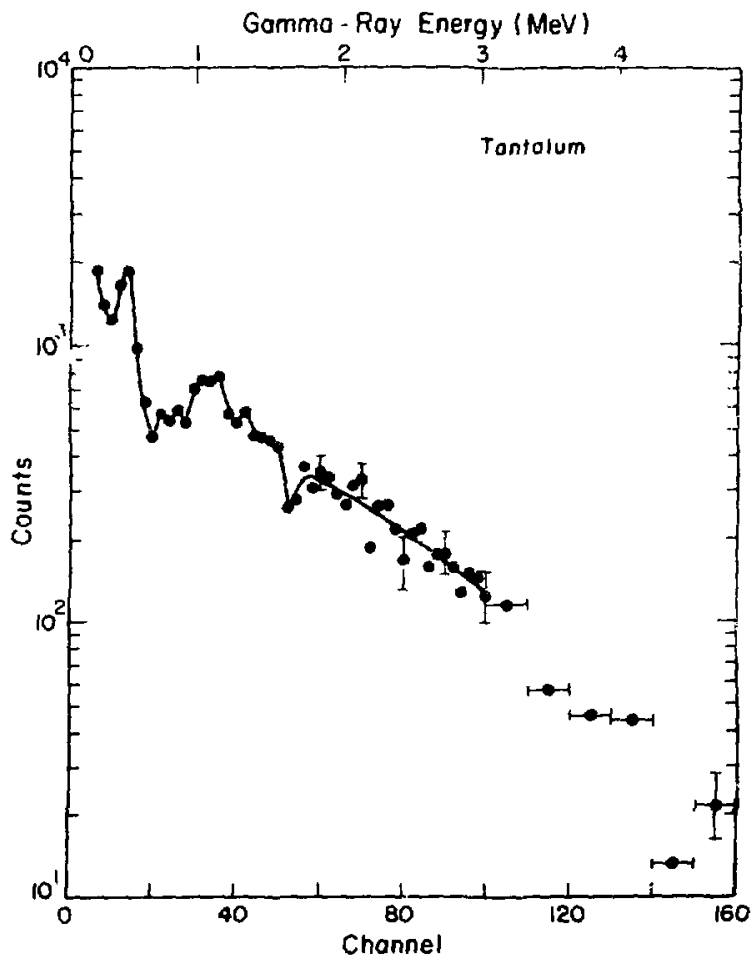

Fig. 11.

Net gamma-ray pulse-height spectrum for tantalum.

the Appendix and indicate that the ratio $R$ for an arbitrary sample can be related to the measured ratio for the iron standard by

$$
R_{s a}=R_{s t} \frac{\left[1-e^{-\left(n_{s s} \sigma_{s a} / 2\right)}\right]}{\left[1-e^{-\left(n_{s t}{ }_{s t} / 2\right)}\right]} .
$$

Here, $\mathrm{R}_{\mathrm{eq}}$ is the ratio of counts in the tail divided by total counts in the toil plus peak observed with a sample, $\sigma_{s c}$ is the scattering cross section of the sample, and $n_{\text {mal }}$ is the areal density of the sample. The equiralent quantities for the standard (here taken as iron) are $R_{\mathrm{at}}, \sigma_{\mathrm{At}}$, and $\mathrm{n}_{\mathrm{At}}$. By this inethod the ration $R$ was obtained for all of the samples used in the experiment.

Finally, the gamma-ray line shapes obtained from the detecior were dencribed in terms of (1) a Gaursicn distribution around the peak energy with (2) a relatively flat tail extending to zoro onergy. The rotio $\mathrm{R}$ was parametrized over the 0.2- to $10-\mathrm{M} * \mathrm{~V}$ gammoray energy range. This information, with the absoluts efficiency of the detector, wat incorporated into NIBL, which derived the dexired photon apectra by 
successively stripping $\mathrm{Nal}(\mathrm{Tl})$ response functions from the net $\mathrm{NaI}(\mathrm{Tl})$ epectra.

\section{Noutron Flux Moasuremente}

During this experiment, several separate mecosurements were made of the absolute neutron intensity. Two proton-recoil telescopes with different geometrical arrangements were used. Both counters used silicon and NaI(Tl) detectors in a coincidence arrangement to distinguish the recoil proton pulsos from other pulses. A large resolving time ( 5- to 8 . $\mu s)$ was used in the coincidence circuit to ensure that no proton pulses were lost due to time jitter. Further, electronic livetime (greater than $99 \%$ ) was mecsured by connecting a $60-\mathrm{Hz}$ pulser to the test inful of both preamplifiers and computing the ratio of the number of these pulses that appeared in the spectra to the number of times the pulser fired.

The neutron intensity was measured as a function of the gas cell pressure and beam current over the small pressure range used in these experiments. All of the measurements agreed to within $5 \%$ with the neutron intensity calculations, which were made using appropriate srose sections for the ${ }^{2} \mathrm{Z} I(t, n)^{4} \mathrm{H}_{e}$

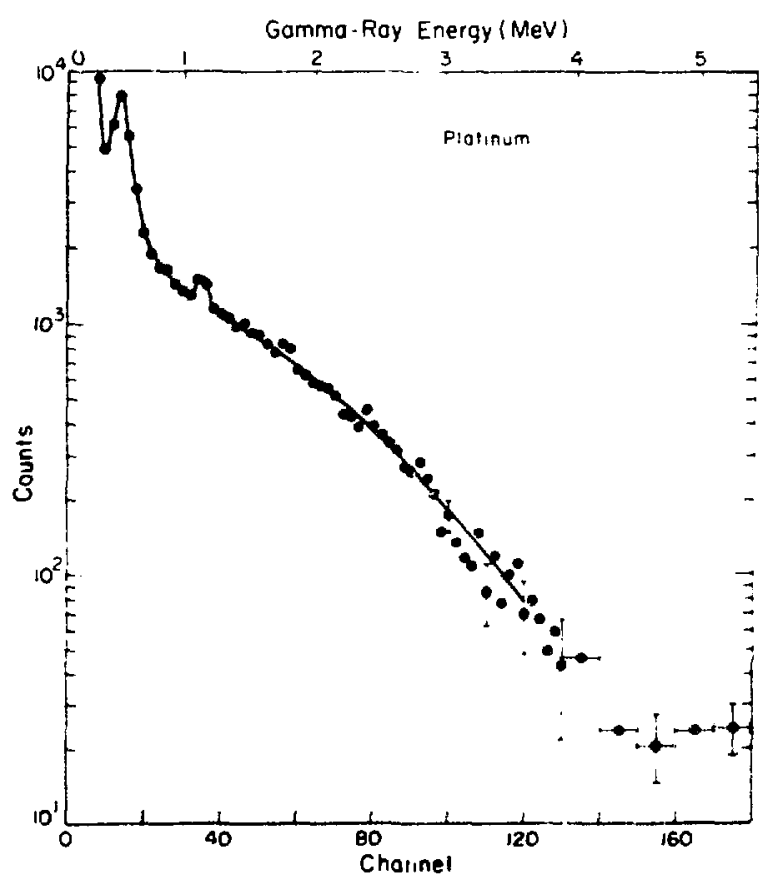

Fig. 12.

Net gamma-ray pulse-height spectrum for platinum.

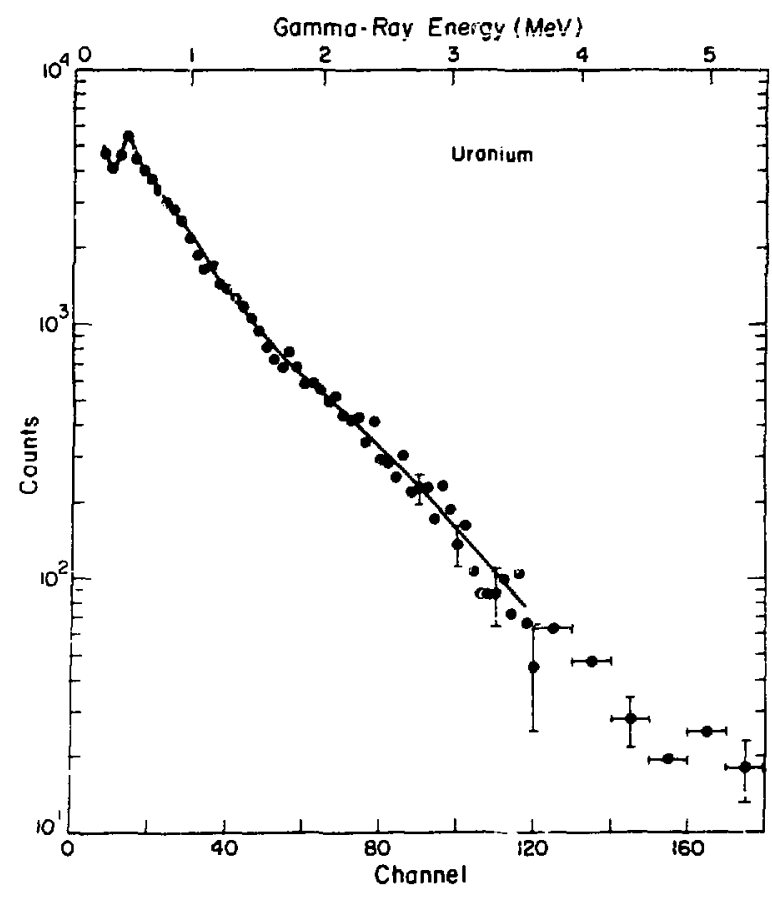

Fig. 13.

Net gamma-ray pulse-height spectrum for $235 \mathrm{U}$.

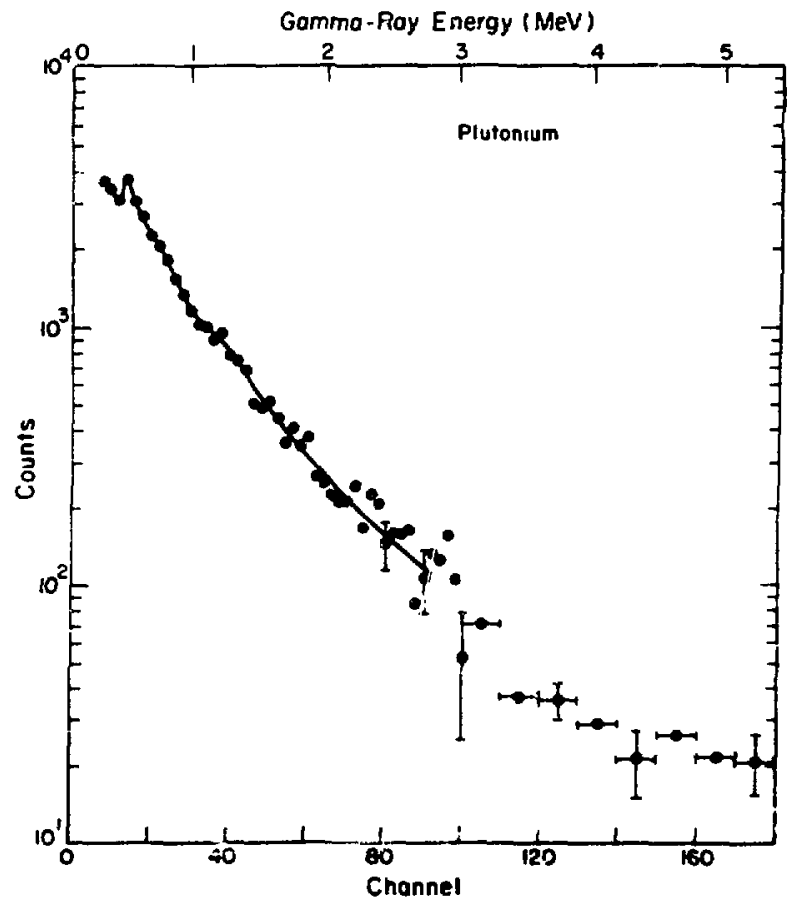

Fig. 14.

Ner gamma-ray pulse-height spectrum for ${ }^{239} \mathrm{Pu}$. 


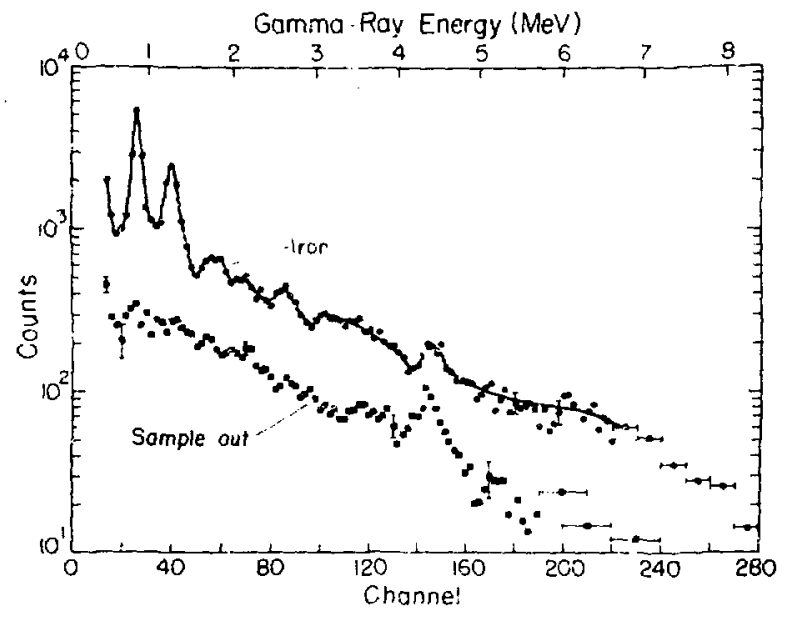

Fig. 15.

Pulse-height spectrum for iron (time-independent background was subiracted) and a corresponding nosample pislse-height spectrum.

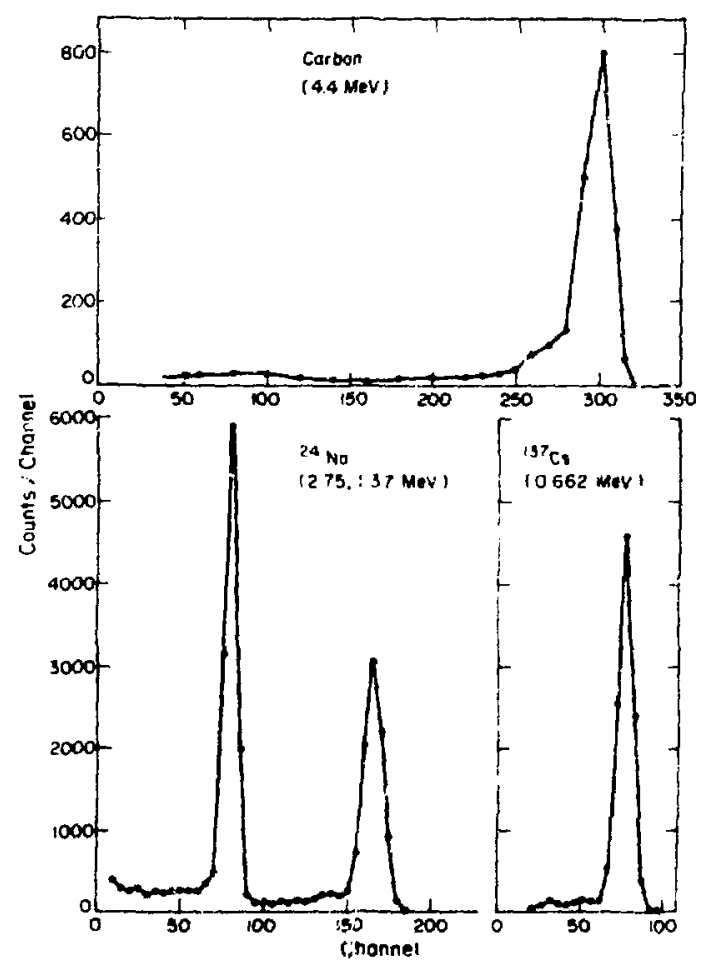

Fig. 16.

Gamma-ray pulse-height spectra for monoenergetic gamma rays. The 4.4-MeV line was obtained from neutron bombardment of carban; the other lires were ob. lained from radioactive sources of ${ }^{24} \mathrm{Na}$ and ${ }^{137} \mathrm{Cs}$.

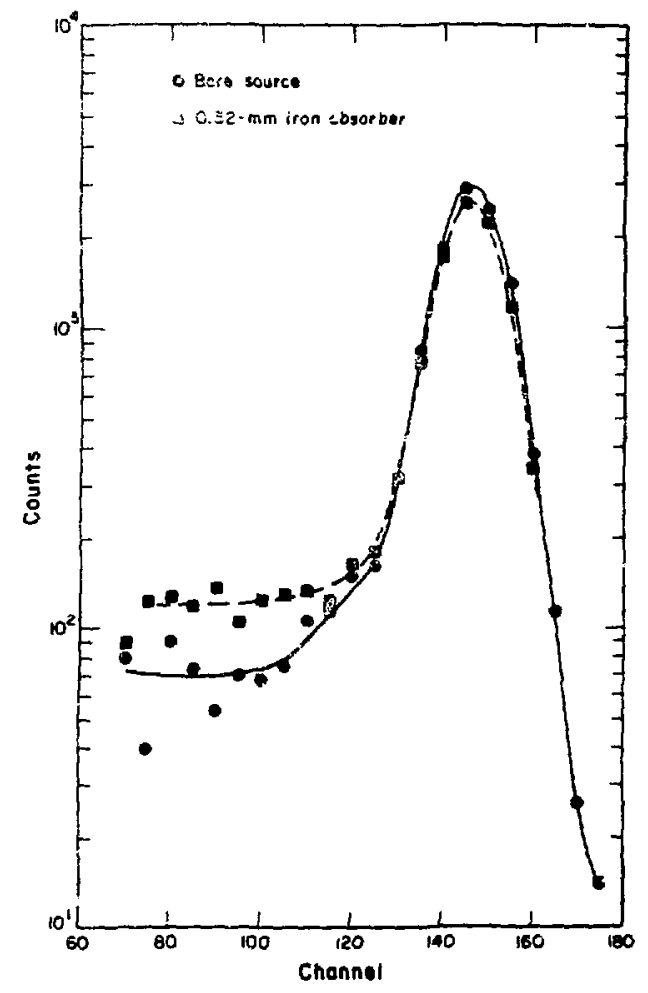

Fig. 17.

Gamma-ray pulse-height spectnum for the 1.27$\mathrm{MeV}$ gamma ray from ${ }^{22} \mathrm{Na}$ with $(\longrightarrow)$ ) and withoul $(\longrightarrow)$ an iron absorber. This figure shows the effect of the gamma-ray production sample in modifying bare source response functions.

reaction, trrget preseurs, und beam current. Figure 18 shows the coincident pulse-hoight spectra abtained for the silicon and NaI detectors, with and without the polyethylene foil. Telescope efficiency was calculated using the geometrical corrections described by Hansen ot al. ${ }^{l}$ and the $H(n, p) n$ cross sections of Hopkins and Breit. ${ }^{2}$

\section{Multiple Scartering}

The multiple scattering effect of neutrons in the samples was estimated using the code MCN. ${ }^{3}$ For the nonfissionable samples, the corrsction was applied to the dati as a function of gamma-ray energy. In general, a nonelastic collision in any of the samples reduces the neutron energy to such on exterst that a second nonelastic collision cannot produce high. energy gamma rays. Therefore, the full magnitude of the correction indicated by MCN was applied to the 


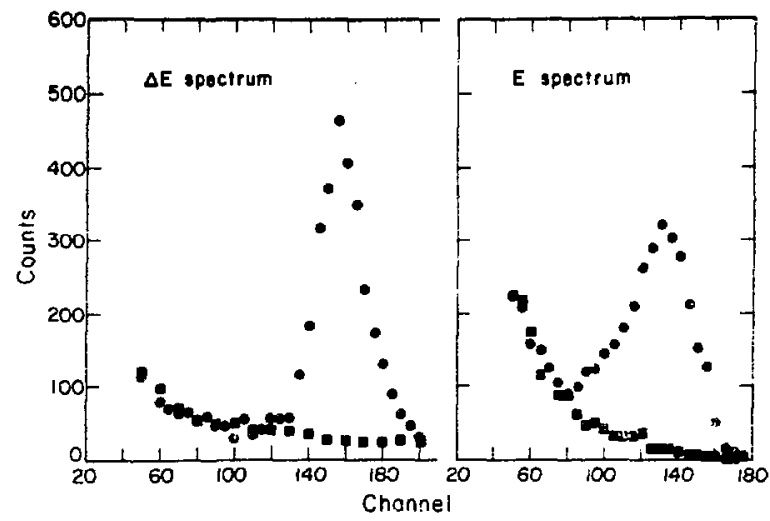

Fig. 18.

Pulse-height spectia for the proton recoil ielescope for both $\Delta E$ (silicon) and $E[N a I(T I)]$ detectors. Squares represent background counts with the polyethylene radiator removed.

low-energy (0.5-MeV) part of the gamma-ray spectrum and was decreased linearly to zero at $8 \mathrm{MeV}$. This rather arbitrary procedure introduces cnly small uncertainties because the multiple scattering effect is only about $4 \%$ or less.

For the fissionable elements, the correction was applied to the entire spectrum because most of the gamma rays are associated with fission fragments and the spectrum shape is not altergd by multiple scattering.

\section{E. Crose-Section Calculation:}

Differential cross sections were calculated for gamma-ray preduction as a funcition of gamma-ray energy by

$$
\sigma\left(E_{\gamma}, \theta\right)=\frac{N_{\gamma} \times d^{2}}{F \times \in\left(E_{\gamma}\right) \times N},
$$

where $\mathrm{N}_{\gamma}$ is the number of gamma raya in an energy interval, $\mathrm{d}^{2}$ is the harmonic mear of the square of the distance from the neutron source to the somple, $F$ is the time-integrated neutron flux, $c\left(E_{y}\right)$ is the efficiency of the gamma-roy spoctrometer for gamma-ray ennzgy $E_{\gamma}$, and $N$ in the number of ample atomo. Corrections wore mado for multiple scattering of neutrore in tine sample ( $\leq 5 \%)$, deadtime $(\sim 5-8 \%)$, and gamma-ray attenuation in the sample.

\section{ESTIMATE OF ERRORS}

Uncertainties in the gamma-ray detector efficiency were estimated to be $\pm 3 \%$ from 0.5 to $3 \mathrm{MeV}$, increasing to $\pm 12 \%$ at $8 \mathrm{MeV}$.

Neutron flux measurements were very consistent throughout the experiment, and the uncertainty in the flux was taken to be $\pm 7 \%$.

Errors introduced by the unfolding program, including the use of imperfect response functions, were taken to be $\pm 5 \%$.

Multiple scattering correctiuns were typically less than $5 \%$. The uncertainty assigned to this correction was taken to be half the value indicated by the $\mathrm{MCN}$ code.

Precision of the measurement of the sample position relative to the neutron source was about $\pm \mathrm{lmm}$. This introduced an uncertainty of about $\pm 3 \%$ in cross sections.

Statistical standard deviations were added in yuadrature to the above uncertainties and ase included in the cross-section tables.

\section{RESULTS}

Cross sections fo: gamma-ray production on all samples included in this report except carbon are listed in Tuble I. Table II lists croses sections for those gamma rays thrt can be andiyzed an indivitual lines. In Table I cross sections are listed as millibarns per steradian in $100-\mathrm{keV}$ intervals from 300 to $4000 \mathrm{keV}$, and in $500-\mathrm{keV}$ intervals above $4000 \mathrm{keV}$. The energy-woighted integral cross sections, $S \mathrm{E}_{\gamma} \sigma\left(\mathrm{E}_{\gamma}\right)$ $\mathrm{dE}_{\gamma}$, for ${ }^{235 \mathrm{~V}}$ and ${ }^{239} \mathrm{Pu}$ from 0.3 to $9 \mathrm{MeV}$ aro $23.5 \pm 2.8$ and $25.4 \pm 3.0 \mathrm{MeV} \cdot \mathrm{b}$, respectively.

Table II lists cross sections for separable gamma rays for the lighter elements (carbon through iron). Some of threse cross sections might include some nearby garnma rays. For example, the $0.84-\mathrm{MeV}$ gamma-ray' cross section listed for iron probably contains some of the $0.93-\mathrm{MeV}$ gamme rays from the ${ }^{56} \mathrm{Fe}(n, 2 n)^{55} \mathrm{Fe}$ reaction. There are some peaks in the spectra for heavier elemente, but no attempt was made to analyze them as single gamma rays. 
TABLE I

DIFFERENTIAL GAMMA-RAY PRODUCTION CROSS SECTIONS AS A FUNCTION OF GAMMA-RAY ENERGY

\begin{tabular}{|c|c|c|c|c|c|c|c|c|c|c|c|c|}
\hline \multirow{2}{*}{$\begin{array}{l}\text { Element } \rightarrow \\
\text { Angle } \rightarrow\end{array}$} & \multicolumn{4}{|c|}{ MAGNESIUH } & \multirow{2}{*}{\multicolumn{2}{|c|}{$\frac{\text { ALUMINUM }}{128^{\circ}}$}} & \multirow{2}{*}{\multicolumn{2}{|c|}{$\frac{\text { CHROMIUM }}{120^{\circ}}$}} & \multicolumn{4}{|c|}{ IRON } \\
\hline & \multicolumn{2}{|c|}{$90^{\circ}$} & \multicolumn{2}{|c|}{$128^{\circ}$} & & & & & \multicolumn{2}{|c|}{$90^{\circ}$} & \multicolumn{2}{|c|}{$120^{\circ}$} \\
\hline $\begin{array}{c}\text { Energy } \\
\text { Interval } \\
\text { (Mev) } \\
\end{array}$ & $\begin{array}{l}\text { Cross } \\
\text { Section } \\
\text { (mb/sr) }\end{array}$ & $\begin{array}{l}\text { Est } \\
\text { Uncer- } \\
\text { tainty } \\
\text { (mb/sr) }\end{array}$ & $\begin{array}{c}\text { Cross } \\
\text { Section } \\
(m b / s r)\end{array}$ & $\begin{array}{l}\text { Est } \\
\text { Uncer- } \\
\text { tainty } \\
\text { (mb/sn) }\end{array}$ & $\begin{array}{c}\text { Cross } \\
\text { Section } \\
(\mathrm{mb} / \mathrm{sn}) \\
\end{array}$ & $\begin{array}{l}\text { Est } \\
\text { Uncer- } \\
\text { tainty } \\
(m b / s r)\end{array}$ & $\begin{array}{l}\text { Cross } \\
\text { Section } \\
(\mathrm{mb} / \mathrm{sr})\end{array}$ & $\begin{array}{l}\text { Est } \\
\text { Uncer- } \\
\text { tainty } \\
\text { (mb/sr) }\end{array}$ & $\begin{array}{l}\text { Cross } \\
\text { Section } \\
(\mathrm{mb} / \mathrm{sr})\end{array}$ & $\begin{array}{l}\text { Est } \\
\text { Uncer- } \\
\text { tainty } \\
\text { (mb/sr) }\end{array}$ & $\begin{array}{l}\text { Cross } \\
\text { Section } \\
(m b / s r)\end{array}$ & $\begin{array}{l}\text { Est } \\
\text { Uncer- } \\
\text { tainty } \\
\text { (mb/sr) }\end{array}$ \\
\hline $\begin{array}{l}0.3-0.4 \\
0.4=0.5 \\
0.5-0.6 \\
0.6=0.7 \\
0.7-0.8 \\
0.8-0.9 \\
0.9=1.0\end{array}$ & $\begin{array}{l}5.1 \\
2.8 \\
1.7 \\
0.56 \\
1.5 \\
2.7 \\
2.0 \\
\end{array}$ & $\begin{array}{l}0.6 \\
0.4 \\
0.3 \\
0.21 \\
0.2 \\
0.3 \\
0.3\end{array}$ & $\begin{array}{l}7.2 \\
3.7 \\
1.8 \\
0.36 \\
2.0 \\
2.3 \\
2.0\end{array}$ & $\begin{array}{l}1.0 \\
0.8 \\
0.5 \\
0.46 \\
0.5 \\
0.5 \\
0.5\end{array}$ & $\begin{array}{l}2.3 \\
3.2 \\
0.61 \\
0.0 \\
3.2 \\
3.4 \\
6.0\end{array}$ & $\begin{array}{l}0.6 \\
0.6 \\
0.36 \\
0.35 \\
0.5 \\
0.5 \\
0.7\end{array}$ & $\begin{array}{r}6.5 \\
9.8 \\
9.1 \\
9.8 \\
10.4 \\
10.5 \\
12.2\end{array}$ & $\begin{array}{l}0.9 \\
1.1 \\
1.0 \\
1.1 \\
1.1 \\
1.1 \\
1.3\end{array}$ & $\begin{array}{r}6.2 \\
12.1 \\
8.3 \\
5.0 \\
15.0 \\
34.5 \\
11.8\end{array}$ & $\begin{array}{l}0.6 \\
1.3 \\
0.3 \\
0.5 \\
1.5 \\
3.5 \\
1.2\end{array}$ & $\begin{array}{r}8.1 \\
10.2 \\
4.2 \\
1.8 \\
15.7 \\
43.4 \\
12.8\end{array}$ & $\begin{array}{l}1.3 \\
1.2 \\
0.3 \\
0.7 \\
2.0 \\
4.6 \\
1.5\end{array}$ \\
\hline $\begin{array}{l}1.0-1.1 \\
1.1-1.2 \\
1.2-1.3 \\
1.3=1.4 \\
1.4-1.5 \\
1.5-1.6 \\
1.6-1.7 \\
1.7-1.8 \\
1.8-1.9 \\
1.9-2.0\end{array}$ & $\begin{array}{r}1.9 \\
2.8 \\
5.5 \\
16.5 \\
0.3 \\
2.2 \\
2.3 \\
3.6 \\
3.6 \\
2.0\end{array}$ & $\begin{array}{l}0.3 \\
0.3 \\
0.6 \\
1.7 \\
0.9 \\
0.3 \\
0.3 \\
0.4 \\
0.4 \\
0.2\end{array}$ & $\begin{array}{r}1.5 \\
2.3 \\
6.2 \\
17.9 \\
8.5 \\
1.3 \\
1.8 \\
3.1 \\
3.4 \\
2.5\end{array}$ & $\begin{array}{l}0.5 \\
0.5 \\
0.8 \\
1.9 \\
1.0 \\
0.4 \\
0.4 \\
0.5 \\
0.5 \\
0.4\end{array}$ & $\begin{array}{l}4.1 \\
1.2 \\
1.5 \\
1.3 \\
1.2 \\
1.4 \\
3.1 \\
7.1 \\
6.5 \\
2.9\end{array}$ & $\begin{array}{l}0.5 \\
0.3 \\
0.3 \\
0.3 \\
0.3 \\
0.3 \\
0.4 \\
0.8 \\
0.7 \\
0.4\end{array}$ & $\begin{array}{r}5.0 \\
6.1 \\
11.6 \\
29.5 \\
33.7 \\
12.4 \\
2.8 \\
3.4 \\
2.2 \\
2.3\end{array}$ & $\begin{array}{l}0.6 \\
0.6 \\
1.2 \\
3.0 \\
3.4 \\
1.3 \\
0.4 \\
0.4 \\
0.3 \\
0.3\end{array}$ & $\begin{array}{r}6.5 \\
9.7 \\
18.6 \\
10.0 \\
4.1 \\
2.7 \\
3.6 \\
4.5 \\
4.3 \\
3.1\end{array}$ & $\begin{array}{l}0.7 \\
1.1 \\
1.8 \\
1.0 \\
0.4 \\
0.3 \\
0.4 \\
0.5 \\
0.5 \\
0.3\end{array}$ & $\begin{array}{r}6.9 \\
11.0 \\
23.3 \\
13.3 \\
4.9 \\
3.0 \\
4.0 \\
5.4 \\
4.7 \\
3.6\end{array}$ & $\begin{array}{l}0.8 \\
1.4 \\
2.4 \\
1.4 \\
0.6 \\
0.5 \\
0.5 \\
0.6 \\
0.6 \\
0.4\end{array}$ \\
\hline $\begin{array}{l}2.0-2.1 \\
2.1-2.2 \\
2.2-2.3 \\
2.3-2.4 \\
2.4-2.5 \\
2.5-2.6 \\
2.6-2.7 \\
2.7-2.8 \\
2.8-2.3 \\
2.9-3.0 \\
\end{array}$ & $\begin{array}{l}1.1 \\
1.0 \\
0.97 \\
0.98 \\
1.3 \\
1.4 \\
1.7 \\
1.9 \\
1.7 \\
1.1 .\end{array}$ & $\begin{array}{l}0.2 \\
0.2 \\
0.15 \\
0.14 \\
0.2 \\
0.2 \\
0.2 \\
0.2 \\
0.2 \\
0.1\end{array}$ & $\begin{array}{l}1.1 \\
0.75 \\
0.49 \\
1.1 \\
0.93 \\
1.4 \\
1.8 \\
2.3 \\
2.0 \\
1.2\end{array}$ & $\begin{array}{l}0.3 \\
0.27 \\
0.25 \\
0.3 \\
0.24 \\
0.3 \\
0.3 \\
0.3 \\
0.3 \\
0.3\end{array}$ & $\begin{array}{l}2.4 \\
4.7 \\
6.0 \\
3.6 \\
2.3 \\
1.7 \\
1.3 \\
1.4 \\
1.9 \\
3.7\end{array}$ & $\begin{array}{l}0.3 \\
0.5 \\
0.7 \\
0.4 \\
0.3 \\
0.3 \\
0.2 \\
0.2 \\
0.3 \\
0.4\end{array}$ & $\begin{array}{l}2.6 \\
2.2 \\
2.3 \\
2.3 \\
1.7 \\
1.8 \\
1.6 \\
1.7 \\
1.6 \\
1.7\end{array}$ & $\begin{array}{l}0.4 \\
0.3 \\
0.3 \\
0.3 \\
0.3 \\
0.2 \\
0.2 \\
0.2 \\
0.2 \\
0.2\end{array}$ & $\begin{array}{l}2.9 \\
3.0 \\
2.3 \\
2.2 \\
2.7 \\
3.2 \\
2.7 \\
2.1 \\
1.9 \\
1.9\end{array}$ & $\begin{array}{l}0.3 \\
0.3 \\
0.3 \\
0.3 \\
0.3 \\
0.4 \\
0.3 \\
0.2 \\
0.2 \\
0.2\end{array}$ & $\begin{array}{l}3.2 \\
3.2 \\
2.4 \\
2.5 \\
2.7 \\
3.5 \\
3.2 \\
2.4 \\
2.0 \\
2.1\end{array}$ & $\begin{array}{l}0.4 \\
0.4 \\
0.3 \\
0.4 \\
0.4 \\
0.5 \\
0.4 \\
0.3 \\
0.3 \\
0.3\end{array}$ \\
\hline $\begin{array}{l}3.0-3.1 \\
3.1-3.2 \\
3.2-3.3 \\
3.3-3.4 \\
3.4=3.5 \\
3.5=3.6 \\
3.6=3.7 \\
3.7-3.8 \\
3.8-3.9 \\
3.9-4.0\end{array}$ & $\begin{array}{l}0.97 \\
0.79 \\
0.67 \\
0.54 \\
0.75 \\
0.69 \\
0.92 \\
1.34 \\
1.5 \\
1.4\end{array}$ & $\begin{array}{l}0.14 \\
0.12 \\
0.11 \\
0.10 \\
0.12 \\
0.11 \\
0.13 \\
0.2 \\
0.2 \\
0.2\end{array}$ & $\begin{array}{l}1.0 \\
1.1 \\
0.67 \\
0.64 \\
1.1 \\
0.5 \\
0.95 \\
1.0 \\
1.5 \\
1.4\end{array}$ & $\begin{array}{l}0.2 \\
0.2 \\
0.21 \\
0.20 \\
0.2 \\
0.21 \\
0.22 \\
0.2 \\
0.3 \\
0.3\end{array}$ & $\begin{array}{l}3.9 \\
2.4 \\
1.4 \\
0.96 \\
0.62 \\
0.53 \\
0.78 \\
0.90 \\
0.88 \\
1.2\end{array}$ & $\begin{array}{l}0.5 \\
0.3 \\
0.2 \\
0.18 \\
0.16 \\
0.16 \\
0.17 \\
0.18 \\
0.18 \\
0.2\end{array}$ & $\begin{array}{l}2.3 \\
2.3 \\
2.3 \\
1.8 \\
1.3 \\
1.6 \\
1.8 \\
1.5 \\
1.7 \\
1.4\end{array}$ & $\begin{array}{l}0.3 \\
0.3 \\
0.3 \\
0.3 \\
0.2 \\
0.2 \\
0.2 \\
0.2 \\
0.2 \\
0.2\end{array}$ & $\begin{array}{l}1.9 \\
2.0 \\
2.0 \\
1.9 \\
1.9 \\
1.9 \\
1.8 \\
1.7 \\
1.4 \\
1.4\end{array}$ & $\begin{array}{l}0.2 \\
0.2 \\
0.2 \\
0.2 \\
0.2 \\
0.2 \\
0.2 \\
0.2 \\
0.2 \\
0.2\end{array}$ & $\begin{array}{l}2.0 \\
2.2 \\
2.5 \\
2.3 \\
2.2 \\
2.3 \\
2.2 \\
2.0 \\
1.7 \\
1.7\end{array}$ & $\begin{array}{l}0.3 \\
0.3 \\
0.3 \\
0.3 \\
0.3 \\
0.3 \\
0.3 \\
0.3 \\
0.3 \\
0.3\end{array}$ \\
\hline $\begin{array}{l}4.0-4.5 \\
4.5=5.0 \\
5.0=5.5 \\
5.5=6.0 \\
6.0=6.5 \\
6.5=7.0 \\
7.0=7.5 \\
7.5=8.0 \\
8.0=8.5 \\
8.5=9.0\end{array}$ & $\begin{array}{l}1.3 \\
0.71 \\
0.51 \\
0.56 \\
0.56 \\
0.50 \\
0.59 \\
0.64 \\
0.41 \\
0.61\end{array}$ & $\begin{array}{l}1.27 \\
: .23 \\
i .21 \\
0.21 \\
9.24 \\
0.25 \\
0.24 \\
0.22 \\
0.13 \\
0.14\end{array}$ & $\begin{array}{l}1.3 \\
0.71 \\
0.51 \\
0.56 \\
0.56 \\
0.50 \\
0.59 \\
0.64 \\
0.41 \\
0.61\end{array}$ & $\begin{array}{l}0.27 \\
0.23 \\
0.21 \\
0.21 \\
0.24 \\
0.25 \\
0.24 \\
0.27 \\
0.13 \\
0.14\end{array}$ & $\begin{array}{l}0.94 \\
0.90 \\
0.75 \\
0.73 \\
0.56 \\
0.49 \\
0.56 \\
0.59 \\
0.32 \\
0.45\end{array}$ & $\begin{array}{l}0.20 \\
0.20 \\
0.19 \\
0.19 \\
0.21 \\
0.24 \\
0.23 \\
0.16 \\
0.11 \\
0.13\end{array}$ & $\begin{array}{l}1.4 \\
1.4 \\
1.2 \\
1.3 \\
1.0 \\
0.87 \\
0.94 \\
0.91 \\
0.91 \\
0.71\end{array}$ & $\begin{array}{l}0.2 \\
0.2 \\
0.2 \\
0.2 \\
0.2 \\
0.24 \\
0.25 \\
0.19 \\
0.18 \\
0.16\end{array}$ & $\begin{array}{l}1.2 \\
1.0 \\
0.99 \\
0.99 \\
0.98 \\
0.98 \\
0.88 \\
0.79 \\
0.69 \\
0.60\end{array}$ & $\begin{array}{l}0.2 \\
0.2 \\
0.14 \\
0.15 \\
0.17 \\
0.18 \\
0.16 \\
0.15 \\
0.13 \\
0.12\end{array}$ & $\begin{array}{l}1.4 \\
1.2 \\
1.2 \\
1.1 \\
1.2 \\
1.1 \\
1.0 \\
0.90 \\
0.79 \\
0.64\end{array}$ & $\begin{array}{l}0.2 \\
0.2 \\
0.2 \\
0.2 \\
0.2 \\
0.2 \\
0.2 \\
0.17 \\
0.18 \\
0.14\end{array}$ \\
\hline
\end{tabular}


TABLE I (cont)

\begin{tabular}{|c|c|c|c|c|c|c|c|c|c|c|}
\hline Element - & \multirow{2}{*}{\multicolumn{2}{|c|}{$\frac{\text { NICKEL }}{120^{\circ}}$}} & \multirow{2}{*}{\multicolumn{2}{|c|}{ COPPER }} & \multicolumn{4}{|c|}{ MOLYBDENUH } & \multicolumn{2}{|c|}{ NIOBEUM } \\
\hline Angle $\quad \rightarrow$ & & & & & $90^{\circ}$ & & $120^{\circ}$ & & & $120^{\circ}$ \\
\hline $\begin{array}{c}\text { Energy } \\
\text { Interval } \\
\text { (MeV) } \\
\end{array}$ & $\begin{array}{l}\text { Cross } \\
\text { Section } \\
\text { (mb/sr) }\end{array}$ & $\begin{array}{l}\text { Est } \\
\text { Uncer- } \\
\text { tainty } \\
\text { (mb/sr) }\end{array}$ & $\begin{array}{l}\text { Cross } \\
\text { Section } \\
(\mathrm{mb} / \mathrm{sr})\end{array}$ & $\begin{array}{l}\text { Est } \\
\text { Uncer- } \\
\text { tainty } \\
\text { (mb/sr) }\end{array}$ & $\begin{array}{l}\text { Cross } \\
\text { Section } \\
(\mathrm{mb} / \mathrm{s} r)\end{array}$ & $\begin{array}{l}\text { Est } \\
\text { Uncer- } \\
\text { tainty } \\
(\mathrm{mb} / \mathrm{sr}) \\
\end{array}$ & $\begin{array}{l}\text { Cross } \\
\text { Section } \\
(\mathrm{mb} / \mathrm{sr}) \\
\end{array}$ & $\begin{array}{l}\text { Est } \\
\text { Uncer- } \\
\text { tainty } \\
\text { (mb/sr) } \\
\end{array}$ & $\begin{array}{l}\text { Cross } \\
\text { Section } \\
(\mathrm{mb} / \mathrm{s})\end{array}$ & $\begin{array}{l}\text { Est } \\
\text { Uncer- } \\
\text { tainty } \\
\text { (mb/sr) } \\
\end{array}$ \\
\hline $\begin{array}{l}0.3-0.4 \\
0.4=0.5 \\
0.5-0.6 \\
0.6-0.7 \\
0.7-0.6 \\
0.8=0.9 \\
0.9-1.0\end{array}$ & $\begin{array}{r}12.1 \\
13.2 \\
3.7 \\
2.5 \\
5.0 \\
4.6 \\
8.2\end{array}$ & $\begin{array}{l}1.3 \\
1.4 \\
0.5 \\
0.4 \\
0.5 \\
0.5 \\
0.8\end{array}$ & $\begin{array}{r}22.0 \\
15.8 \\
10.1 \\
10.1 \\
6.7 \\
10.6 \\
21.0\end{array}$ & $\begin{array}{l}2.4 \\
1.7 \\
1.1 \\
1.1 \\
0.7 \\
1.0 \\
2.1\end{array}$ & $\begin{array}{r}-.- \\
20.3 \\
29.4 \\
52.5 \\
42.9 \\
22.6\end{array}$ & $\begin{array}{l}--- \\
2.0 \\
2.1 \\
3.0 \\
5.3 \\
4.3 \\
2.3\end{array}$ & $\begin{array}{l}22.1 \\
27.6 \\
24.5 \\
40.6 \\
63.4 \\
46.3 \\
25.5\end{array}$ & $\begin{array}{l}2.5 \\
3.5 \\
2.9 \\
4.5 \\
6.7 \\
4.8 \\
2.7\end{array}$ & $\begin{array}{l}29.4 \\
30.5 \\
17.6 \\
12.2 \\
16.7 \\
14.9 \\
25.2\end{array}$ & $\begin{array}{l}3.2 \\
3.3 \\
1.9 \\
1.5 \\
1.8 \\
1.7 \\
2.6\end{array}$ \\
\hline $\begin{array}{l}1.0=1.1 \\
1.1=1.2 \\
1.2=1.3 \\
1.3=1.4 \\
1.4=1.5 \\
1.5=1.6 \\
1.6=1.7 \\
1.7=1.8 \\
1.8=1.9 \\
1.9-2.0\end{array}$ & $\begin{array}{r}9.1 \\
12.5 \\
15.4 \\
18.8 \\
16.1 \\
7.5 \\
4.5 \\
4.6 \\
4.2 \\
2.9\end{array}$ & $\begin{array}{l}0.9 \\
1.2 \\
1.5 \\
1.9 \\
1.6 \\
0.8 \\
0.4 \\
0.5 \\
0.5 \\
0.3\end{array}$ & $\begin{array}{r}16.8 \\
23.9 \\
15.8 \\
13.3 \\
9.9 \\
7.3 \\
5.9 \\
5.0 \\
5.6 \\
4.5\end{array}$ & $\begin{array}{l}1.7 \\
2.4 \\
1.6 \\
1.4 \\
1.0 \\
0.8 \\
0.7 \\
0.5 \\
0.6 \\
0.5\end{array}$ & $\begin{array}{r}20.7 \\
16.6 \\
11.3 \\
10.5 \\
13.3 \\
14.1 \\
9.8 \\
7.7 \\
6.3 \\
5.9\end{array}$ & $\begin{array}{l}2.1 \\
1.7 \\
1.2 \\
1.1 \\
1.3 \\
1.4 \\
1.0 \\
0.8 \\
0.7 \\
0.6\end{array}$ & $\begin{array}{r}23.8 \\
18.6 \\
12.2 \\
11.6 \\
15.1 \\
14.7 \\
9.7 \\
7.4 \\
6.4 \\
6.1\end{array}$ & $\begin{array}{l}2.6 \\
2.0 \\
1.3 \\
1.3 \\
1.7 \\
1.6 \\
1.1 \\
0.8 \\
0.7 \\
0.7\end{array}$ & $\begin{array}{r}14.4 \\
11.6 \\
7.9 \\
9.7 \\
9.4 \\
8.1 \\
7.2 \\
4.4 \\
6.0 \\
6.2\end{array}$ & $\begin{array}{l}1.6 \\
1.3 \\
1.0 \\
1.2 \\
1.1 \\
2.0 \\
0.9 \\
0.7 \\
0.8 \\
0.8\end{array}$ \\
\hline $\begin{array}{l}2.0-2.1 \\
2.1-2.2 \\
2.2-2.3 \\
2.3-2.4 \\
2.4-2.5 \\
2.5-2.6 \\
2.6-2.7 \\
2.7-2.8 \\
2.8-2.9 \\
2.9-3.0\end{array}$ & $\begin{array}{l}2.4 \\
2.4 \\
2.1 \\
2.2 \\
2.2 \\
2.1 \\
2.3 \\
2.2 \\
2.3 \\
2.4\end{array}$ & $\begin{array}{l}0.3 \\
0.3 \\
0.2 \\
0.2 \\
0.3 \\
0.2 \\
0.3 \\
0.3 \\
0.3 \\
0.3\end{array}$ & $\begin{array}{l}3.4 \\
3.1 \\
2.5 \\
2.5 \\
2.2 \\
2.1 \\
1.9 \\
1.8 \\
1.9 \\
1.7\end{array}$ & $\begin{array}{l}0.4 \\
0.4 \\
0.3 \\
0.3 \\
0.3 \\
0.3 \\
0.2 \\
0.2 \\
0.2 \\
0.2\end{array}$ & $\begin{array}{l}5.5 \\
4.8 \\
4.3 \\
3.3 \\
3.8 \\
3.2 \\
3.0 \\
2.8 \\
2.7 \\
2.2\end{array}$ & $\begin{array}{l}0.6 \\
0.5 \\
0.5 \\
0.4 \\
0.4 \\
0.3 \\
0.3 \\
0.3 \\
0.3 \\
0.2\end{array}$ & $\begin{array}{l}5.5 \\
4.9 \\
4.4 \\
4.2 \\
3.7 \\
3.3 \\
3.0 \\
3.0 \\
2.6 \\
2.3\end{array}$ & $\begin{array}{l}0.7 \\
0.5 \\
0.6 \\
0.5 \\
0.5 \\
0.4 \\
0.4 \\
0.4 \\
0.4 \\
0.3\end{array}$ & $\begin{array}{l}7.3 \\
7.3 \\
6.2 \\
5.0 \\
3.5 \\
3.2 \\
2.2 \\
3.0 \\
2.2 \\
2.4\end{array}$ & $\begin{array}{l}0.9 \\
0.9 \\
0.8 \\
0.6 \\
0.5 \\
0.5 \\
0.4 \\
0.5 \\
0.4 \\
0.4\end{array}$ \\
\hline $\begin{array}{l}3.0-3.1 \\
3.1-3.2 \\
3.2=3.3 \\
3.3-3.4 \\
3.4=3.5 \\
3.5=3.6 \\
3.6=3.7 \\
3.7=3.8 \\
3.8=3.9 \\
3.9=4.0\end{array}$ & $\begin{array}{l}2.5 \\
2.3 \\
2.1 \\
1.9 \\
1.5 \\
1.4 \\
1.4 \\
1.3 \\
1.3 \\
1.1\end{array}$ & $\begin{array}{l}0.3 \\
0.3 \\
0.3 \\
0.2 \\
0.2 \\
0.2 \\
0.2 \\
0.2 \\
0.2 \\
0.2\end{array}$ & $\begin{array}{l}1.7 \\
1.6 \\
1.6 \\
1.6 \\
1.5 \\
1.3 \\
1.4 \\
1.3 \\
1.3 \\
1.1\end{array}$ & $\begin{array}{l}0.2 \\
0.2 \\
0.2 \\
0.2 \\
0.2 \\
0.2 \\
0.2 \\
0.2 \\
0.2 \\
0.2\end{array}$ & $\begin{array}{l}2.0 \\
2.0 \\
1.8 \\
1.7 \\
1.6 \\
1.4 \\
1.3 \\
1.3 \\
1.2 \\
1.1\end{array}$ & $\begin{array}{l}0.2 \\
0.2 \\
0.2 \\
0.2 \\
0.2 \\
0.2 \\
0.2 \\
0.2 \\
0.2 \\
0.1\end{array}$ & $\begin{array}{l}2.3 \\
1.9 \\
2.0 \\
1.7 \\
1.4 \\
1.4 \\
1.3 \\
1.0 \\
1.2 \\
1.0\end{array}$ & $\begin{array}{l}0.3 \\
0.3 \\
0.3 \\
0.3 \\
0.3 \\
0.3 \\
0.3 \\
0.2 \\
0.2 \\
0.2\end{array}$ & $\begin{array}{l}1.6 \\
1.3 \\
1.7 \\
1.5 \\
0.45 \\
1.1 \\
1.2 \\
0.68 \\
1.3 \\
0.86\end{array}$ & $\begin{array}{l}0.4 \\
0.4 \\
0.4 \\
0.4 \\
0.31 \\
0.3 \\
0.3 \\
0.33 \\
0.3 \\
0.32\end{array}$ \\
\hline $\begin{array}{l}4.0=4.5 \\
4.5-5.0 \\
5.0=5.5 \\
5.5=6.0 \\
6.0-6.5 \\
6.5-7.0 \\
7.0=7.5 \\
7.5=8.0 \\
8.0-8.5 \\
8.5=9.0\end{array}$ & $\begin{array}{l}1.2 \\
1.1 \\
1.1 \\
0.96 \\
0.92 \\
0.81 \\
0.77 \\
0.67 \\
0.54 \\
0.36\end{array}$ & $\begin{array}{l}0.2 \\
0.2 \\
0.2 \\
0.17 \\
0.18 \\
0.18 \\
0.16 \\
0.13 \\
0.13 \\
0.08\end{array}$ & $\begin{array}{l}1.2 \\
0.95 \\
0.81 \\
0.78 \\
0.64 \\
0.59 \\
0.40 \\
0.29 \\
0.15 \\
0.13\end{array}$ & $\begin{array}{l}0.2 \\
0.17 \\
0.15 \\
0.15 \\
0.15 \\
0.15 \\
0.11 \\
0.07 \\
0.05 \\
0.05\end{array}$ & $\begin{array}{l}0.95 \\
0.69 \\
0.51 \\
0.45 \\
0.39 \\
0.26 \\
0.23 \\
0.15 \\
0.09 \\
0.08\end{array}$ & $\begin{array}{l}0.14 \\
0.11 \\
0.10 \\
0.09 \\
0.09 \\
0.09 \\
0.07 \\
0.05 \\
0.03 \\
0.03\end{array}$ & $\begin{array}{l}0.83 \\
0.66 \\
0.52 \\
0.46 \\
0.38 \\
0.33 \\
0.26 \\
0.17 \\
0.14 \\
0.13\end{array}$ & $\begin{array}{l}0.24 \\
0.23 \\
0.24 \\
0.29 \\
0.28 \\
0.25 \\
0.14 \\
0.11 \\
0.08 \\
0.08\end{array}$ & $\begin{array}{l}0.56 \\
0.65 \\
0.29 \\
0.35 \\
0.33 \\
0.30 \\
0.30 \\
0.12 \\
0.14 \\
0.13\end{array}$ & $\begin{array}{l}0.33 \\
0.28 \\
0.30 \\
0.30 \\
0.32 \\
0.38 \\
0.31 \\
0.14 \\
0.14 \\
0.12\end{array}$ \\
\hline
\end{tabular}


TABLE I (cont)

\begin{tabular}{|c|c|c|c|c|c|c|c|c|}
\hline Ilement + & \multicolumn{2}{|c|}{ TANTALUM } & \multicolumn{2}{|c|}{ PLATINUM } & \multicolumn{2}{|c|}{ URANIUM } & \multicolumn{2}{|c|}{ PLUTONIUA } \\
\hline Angle & & $20^{\circ}$ & & $22^{\circ}$ & & $20^{\circ}$ & & $120^{\circ}$ \\
\hline $\begin{array}{c}\text { Energy } \\
\text { Interval } \\
\text { (MeV) } \\
\end{array}$ & $\begin{array}{l}\text { Cross } \\
\text { Section } \\
(\mathrm{mb} / \mathrm{s} n)\end{array}$ & $\begin{array}{l}\text { Est } \\
\text { Uncer- } \\
\text { tainty } \\
\text { (mb/sr) }\end{array}$ & $\begin{array}{c}\text { Cross } \\
\text { Section } \\
\text { (mb/sr) }\end{array}$ & $\begin{array}{c}\text { Est } \\
\text { Uncer- } \\
\text { tainty } \\
\text { (mb/sr) }\end{array}$ & $\begin{array}{c}\text { Cross } \\
\text { Section } \\
(\mathrm{mb} / \mathrm{sr}) \\
\end{array}$ & $\begin{array}{l}\text { Est } \\
\text { Uncer- } \\
\text { tainty } \\
\text { (mb/sr) }\end{array}$ & $\begin{array}{l}\text { Cross } \\
\text { Section } \\
\text { (mb/sr) }\end{array}$ & $\begin{array}{l}\text { Est } \\
\text { Uncer- } \\
\text { tainty } \\
\text { (mb/sr) }\end{array}$ \\
\hline $\begin{array}{l}0.3-0.4 \\
0.4-0.5 \\
0.3-0.6 \\
0.6-0.7 \\
0.7=0.8 \\
0.8=0.9 \\
0.9-1.0\end{array}$ & $\begin{array}{l}6.7 .4 \\
71.4 \\
31.0 \\
16.5 \\
15.9 \\
17.3 \\
19.4\end{array}$ & $\begin{array}{l}7.4 \\
7.7 \\
3.7 \\
2.4 \\
2.3 \\
2.4 \\
2.5\end{array}$ & $\begin{array}{l}128 \\
152 \\
88.5 \\
35.6 \\
22.4 \\
20.0 \\
17.6\end{array}$ & $\begin{array}{l}13 \\
15 \\
8.9 \\
3.7 \\
2.4 \\
2.1 \\
1.9\end{array}$ & $\begin{array}{r}201 \\
217 \\
161 \\
130 \\
111 \\
y 3 \\
78\end{array}$ & $\begin{array}{l}20 \\
22 \\
17 \\
13 \\
11 \\
10 \\
7.6\end{array}$ & $\begin{array}{r}281 \\
262 \\
202 \\
154 \\
126 \\
102 \\
81\end{array}$ & $\begin{array}{l}29 \\
27 \\
21 \\
15 \\
13 \\
11 \\
9.6\end{array}$ \\
\hline $\begin{array}{l}1.0-1.1 \\
1.1-1.2 \\
1.2-1.3 \\
1.3-1.4 \\
1.4=1.5 \\
1.5-1.6 \\
1.5-1.7 \\
1.7-1.8 \\
1.8=1.9 \\
1.9-2.0\end{array}$ & $\begin{array}{l}23.3 \\
23.1 \\
16.6 \\
19.0 \\
16.9 \\
13.9 \\
13.4 \\
12.0 \\
12.4 \\
11.5\end{array}$ & $\begin{array}{l}2.8 \\
2.8 \\
2.2 \\
2.4 \\
2.2 \\
1.9 \\
1.8 \\
1.7 \\
1.7 \\
1.5\end{array}$ & $\begin{array}{l}20.3 \\
19.8 \\
16.7 \\
16.8 \\
16.9 \\
16.9 \\
16.2 \\
16.2 \\
13.8 \\
1 i .3\end{array}$ & $\begin{array}{l}2.2 \\
2.1 \\
1.8 \\
1.8 \\
1.8 \\
1.8 \\
1.7 \\
1.7 \\
1.5 \\
1.2\end{array}$ & $\begin{array}{l}63 \\
60 \\
55 \\
48 \\
40 \\
37 \\
34 \\
32 \\
28 \\
25\end{array}$ & $\begin{array}{l}6.4 \\
6.0 \\
5.5 \\
4.8 \\
4.1 \\
3.7 \\
3.3 \\
3.4 \\
2.8 \\
2.6\end{array}$ & $\begin{array}{l}70 \\
65 \\
58 \\
48 \\
40 \\
36 \\
31 \\
29 \\
24 \\
21\end{array}$ & $\begin{array}{l}8.3 \\
8.1 \\
7.3 \\
6.1 \\
4.9 \\
4.5 \\
4.2 \\
3.8 \\
3.1 \\
2.7\end{array}$ \\
\hline $\begin{array}{l}2.0-2.1 \\
2.1-2.2 \\
2.2-2.3 \\
2.3-2.4 \\
2.4-2.5 \\
2.5-2.6 \\
2.6-2.7 \\
2.7-2.8 \\
2.8-2.9 \\
2.9-3.0\end{array}$ & $\begin{array}{r}10.6 \\
11.2 \\
9.6 \\
8.9 \\
7.8 \\
0.7 \\
6.4 \\
6.8 \\
5.8 \\
5.2\end{array}$ & $\begin{array}{l}1.4 \\
1.5 \\
1.3 \\
1.2 \\
1.1 \\
1.0 \\
1.0 \\
1.0 \\
0.9 \\
0.9\end{array}$ & $\begin{array}{r}20.7 \\
8.8 \\
8.3 \\
7.9 \\
7.4 \\
6.5 \\
6.4 \\
5.4 \\
5.3 \\
3.7\end{array}$ & $\begin{array}{l}1.2 \\
1.0 \\
0.9 \\
0.9 \\
0.8 \\
0.7 \\
0.7 \\
0.6 \\
0.6 \\
0.5\end{array}$ & $\begin{array}{l}21 \\
19 \\
18 \\
15 \\
14 \\
23 \\
12 \\
9.9 \\
9.2 \\
8.6\end{array}$ & $\begin{array}{l}2.2 \\
2.1 \\
2.0 \\
1.7 \\
1.5 \\
1.3 \\
1.3 \\
1.1 \\
1.1 \\
1.0\end{array}$ & $\begin{array}{l}20 \\
19 \\
15 \\
14 \\
12 \\
12 \\
10 \\
9.5 \\
9.7 \\
8.0\end{array}$ & $\begin{array}{l}2.8 \\
2.6 \\
2.2 \\
2.1 \\
2.0 \\
2.0 \\
1.8 \\
1.7 \\
1.8 \\
1.6\end{array}$ \\
\hline $\begin{array}{l}3.0-3.1 \\
3.2-3.2 \\
3.2-3.3 \\
3.3-3.4 \\
3.4-3.5 \\
3.5-3.6 \\
3.6-3.7 \\
3.7-3.8 \\
3.8-3.9 \\
3.9-4.0\end{array}$ & $\begin{array}{l}4.7 \\
3.4 \\
4.6 \\
4.1 \\
2.2 \\
2.6 \\
2.3 \\
1.2 \\
3.0 \\
3.8\end{array}$ & $\begin{array}{l}0.9 \\
0.8 \\
0.9 \\
0.8 \\
0.7 \\
0.8 \\
0.7 \\
0.7 \\
0.7 \\
0.7\end{array}$ & $\begin{array}{l}3.1 \\
2.6 \\
3.1 \\
2.3 \\
1.8 \\
1.9 \\
1.4 \\
1.9 \\
1.3 \\
1.5\end{array}$ & $\begin{array}{l}0.5 \\
0.4 \\
0.4 \\
0.4 \\
0.3 \\
0.3 \\
0.3 \\
0.4 \\
0.3 \\
0.3\end{array}$ & $\begin{array}{l}6.2 \\
5.8 \\
5.7 \\
5.3 \\
4.7 \\
3.7 \\
3.6 \\
4.0 \\
4.0 \\
2.9\end{array}$ & $\begin{array}{l}0.9 \\
0.8 \\
0.8 \\
0.8 \\
0.7 \\
0.7 \\
0.6 \\
0.7 \\
0.7 \\
0.7\end{array}$ & $\begin{array}{l}5.7 \\
4.7 \\
8.2 \\
4.5 \\
4.5 \\
2.3 \\
4.3 \\
2.3 \\
3.4 \\
3.6\end{array}$ & $\begin{array}{l}1.4 \\
1.4 \\
2.6 \\
1.3 \\
1.4 \\
1.3 \\
1.3 \\
1.3 \\
1.3 \\
1.3\end{array}$ \\
\hline $\begin{array}{l}4.0-4.5 \\
4.5-5.0 \\
5.0-5.5 \\
5.5-6.0 \\
6.0=6.5 \\
6.5-7.0 \\
7.0-7.5 \\
7.5=8.0 \\
8.0=8.5 \\
8.5-9.0\end{array}$ & $\begin{array}{l}1.2 \\
0.77 \\
0.40 \\
0.60 \\
0.59 \\
0.84 \\
0.37 \\
0.19 \\
0.27 \\
0.30\end{array}$ & $\begin{array}{l}0.7 \\
0.61 \\
0.63 \\
0.64 \\
0.77 \\
0.93 \\
0.60 \\
0.35 \\
0.22 \\
0.24\end{array}$ & $\begin{array}{l}0.66 \\
0.71 \\
0.56 \\
0.14 \\
0.30 \\
0.35 \\
0.17 \\
0.19 \\
0.09 \\
0.08\end{array}$ & $\begin{array}{l}0.29 \\
0.26 \\
0.27 \\
0.27 \\
0.30 \\
0.37 \\
0.19 \\
0.15 \\
0.08 \\
0.07\end{array}$ & $\begin{array}{l}2.6 \\
1.8 \\
1.2 \\
0.7 \\
0.5 \\
0.7 \\
0.6 \\
0.3\end{array}$ & $\begin{array}{l}0.6 \\
0.6 \\
0.6 \\
0.6 \\
0.6 \\
0.7 \\
0.4 \\
0.2\end{array}$ & $\begin{array}{l}1.7 \\
2.4 \\
1.4 \\
0.6 \\
0.8 \\
0.9 \\
0.8 \\
0.5\end{array}$ & $\begin{array}{l}1.2 \\
1.0 \\
1.0 \\
0.6 \\
0.7 \\
0.8 \\
0.4 \\
0.3\end{array}$ \\
\hline
\end{tabular}


TABLE II

\section{DIFFERENTIAL GAMMA-RAY PRODUCTIOÑ CROSS SECTIONS FOR PROMINENT GAMMA RAYS}

\begin{tabular}{|c|c|c|c|}
\hline Element & $\begin{array}{c}\text { Gamma-Ray Energy } \\
\text { (MeV) }\end{array}$ & Angle & $\begin{array}{c}\text { Cross Section } \\
(\mathrm{mb} / \mathrm{sr})\end{array}$ \\
\hline \multirow[t]{4}{*}{ Carbon } & 4.4 & 45 & $21.3 \pm 2.8$ \\
\hline & & 64 & $15.0 \pm 2.0$ \\
\hline & & 90 & $11.6 \pm 1.5$ \\
\hline & & 125 & $16.1 \pm 2.1$ \\
\hline \multirow[t]{6}{*}{ Magnesium } & 1.37 & 122 & $30.3 \pm 3.3$ \\
\hline & & 90 & $27.2 \pm 3.0$ \\
\hline & 1.81 & 122 & $8.3 \pm 1.2$ \\
\hline & & 90 & $8.2 \pm 1.2$ \\
\hline & 2.8 & 122 & $4.2 \pm 0.7$ \\
\hline & & 90 & $6.2 \pm 1.0$ \\
\hline \multirow[t]{5}{*}{ Aluminum } & 0.84 & 122 & $5.4 \pm 1.1$ \\
\hline & 1.01 & 122 & $0.6 \pm 2.1$ \\
\hline & 1.8 & 122 & $16.7 \pm 2.5$ \\
\hline & 2.2 & 122 & $13.5 \pm 2.0$ \\
\hline & 3.0 & 122 & $8.4 \pm 1.3$ \\
\hline Chromium & $1.33+1.44$ & 123 & $76.7 \pm 9.2$ \\
\hline \multirow[t]{4}{*}{ Iron } & 0.845 & 1.22 & $65.6 \pm 7.0$ \\
\hline & & 90 & $53.2 \pm 5.6$ \\
\hline & 1.24 & 122 & $34.0 \pm 4.1$ \\
\hline & & 90 & $27.8 \pm 3.3$ \\
\hline
\end{tabular}

APPENDIX

\section{MODIFICATION OF RESPONSE FUNCTIONS DUE TO PHOTON SCATTERXNG}

Neutron-induced gamma-ray production crosssection measurements usually involve unfolding or stripping of complex pulse-height spectra. Response functions used in the unfolding process are obtained from monoenergetic gamma-ray sources and consist primarily of a Gaussian full-energy peak and a relatively flat tail due to Compton collisions in the detector.

This Appendix shows that for samples of moderate size, this tail can be significantly larger than that measured with the usual gamma-ray sources.

For simplicity, the sample is taken to be a cube with sides $t$ in length and $n$ atoms $/ \mathrm{cm}^{3}, G_{\text {。 }}$ monoenergetic gamma rays are produced uniformly through the sample, $\sigma_{8}$ is the gamma-ray scattering cross section, and the detector area is $\triangle A$ and is located a distance $\mathrm{R}$ from the sample. Also, not is taken to be small.

Assuming that (1) $\left(1-\Delta A / 4 \pi R^{2}\right) \cong 1$, (2) efficiency for scattered gamma rays is the same as the direct gamma rays, and (3) absorption cross section for scattered gamma rays is the same cos for direct gam. ma rays, the ratio of acattered gamma-ray counts to counts from direct gamma rays is (errors caused by assumptions 2 and 3 tend to cancel)

$$
\left(1-e^{-n \sigma_{s} t / 2}\right) \text {. }
$$

For most samples, this is a modest increase in counts ( $13 \%$ for a 6.4-mm-thick sample of iron and 1.27-MeV gamma rays), but for detectors whose bare source response functions hove small tails compared 
to full-energy peaks, the relative magnitude of the tail can be increased significantly (Fig. 3 shows an increase of about $70 \%$ ).

In complex gamma-ray spectra that have been unfolded with bare source response functions, this effect would appear to be an extra continuum of gamma rays.

\section{REFERFNCES}

1. G. Hansen, R. K. Smith, Los Alamos Scientific Laboratory, and G. G. Simons, University of Wyoming, personal communication, May 1974.
2. J. C. Hopkine and G. Breit, "The ${ }^{1} \mathrm{H}(\mathbf{n}, \mathbf{n})^{\mathbf{l}} \mathbf{H}$ Scattering Observables Required for High-Precision Fast-Neutron Measurements," Nucl. Data Tables A9, 137 (1971).

3. E. D. Cashwell, ]. R. Neergaard, W. M. Taylor, and G. D. Turner, "MCN: A Neutron Monte Carlo Code," Los Alamos Scientific Laboratory report LA4751 (January 1972). 